\title{
SOIL CARBON STOCK IN FERTILIZED FOREST STANDS WITH MINERAL SOILS
}

\author{
*Ilze Karklina ${ }^{1,2}$, Andis Lazdins ${ }^{1}$, Aldis Butlers ${ }^{1}$, Jeḷena Stola ${ }^{1}$, Zaiga Anna Zvaigzne ${ }^{1}$, Dana Purviṇa ${ }^{1}$ \\ ${ }^{1}$ Latvian State Forest Research Institute 'Silava', Latvia \\ ${ }^{2}$ University of Latvia, Latvia \\ *Corresponding author's email: ilze.karklina@silava.lv
}

\begin{abstract}
Forest mineral soil is one of the terrestrial carbon pools, and changes in forest management practices can affect the carbon stock in forest soil. The purpose of the study is to estimate temporal fertilization impact on mineral soil organic carbon stock, depending on fertilizers applied, forest stand type, different dominant tree species of the stands. Coniferous and birch forest stands with mineral soil in the central and eastern part of Latvia were selected for the experiment. The fertilizers used were wood ash and nitrogen containing mineral fertilizer. No significant differences in organic carbon stock in $\mathrm{O}$ horizon were detected 2-5 years after fertilization. A tendency of smaller organic carbon stock in upper mineral soil layers $(0-10 \mathrm{~cm}, 10-20 \mathrm{~cm})$ was found in most part of objects. Significantly smaller organic carbon stock was found in upper mineral soil layers $(0-10 \mathrm{~cm}$ and $10-20 \mathrm{~cm})$ in birch stands with wet mineral soil treated with ammonium nitrate if compared to the control plots, possibly due to a different soil moisture regime of forest stands. The positive and significant correlations between soil organic carbon and nitrogen stocks were found in most part of the objects.
\end{abstract}

Key words: wood ash, nitrogen containing mineral fertilizer, organic carbon, forest soil.

\section{Introduction}

Forests have an essential role in the global carbon cycle, and forest soil is one of the terrestrial carbon pools. Changes in carbon stock of boreal forest soils are mainly the result of global warming, deforestation and occasional periods of drought and fire. On average, circa $60 \%$ of carbon is stored in soil of boreal forests (Pan et al., 2011), and mineral soil is the second important carbon pool, reaching $31 \%$ of total forest ecosystem carbon, right after the living tree biomass - 59\% (Kēnina et al., 2019). Organic matter has an impact on quality and structure of soil, chemical and biological properties (Walsh \& McDonnell, 2012).

Several local studies have been carried out in this field. A research in regard to the impact of surface fire on $\mathrm{O}$ layer in a dry Scots pine forest indicated a significant impact on reduction of a carbon stock in $\mathrm{O}$ layer in fire affected forest areas, while no significant changes were detected in mineral soil layers (Bārdule et al., 2017). A study conducted in over-mature Norway spruce stands showed no significant differences between forest site types (Ķēniņa et al., 2018). Furthermore, a study in overmature Scots pine stands showed no trends in $\mathrm{O}$ horizon and mineral soil carbon stock changes regarding the stand age, within the range of 163-218 years (Ķēniņa et al., 2019).

Forest soil fertilization can improve the growth of trees on nutrient-poor site and reduce deficiency of nutrients. Forest fertilization can be commenced during the whole rotation or 10-15 years before the regenerative felling, respectively, forest fertilization can be conducted once during the rotation period or can be repeated to ensure continuously high growth rates (Högberg et al., 2006). Studies in Latvia have reported a short-term impact of forest soil fertilization with wood ash on the growth of stand (Okmanis et al., 2016; Okmanis et al., 2018) while other studies reported a long-term effect of forest soil fertilization on growth of trees (Jansons et al., 2016; Libiete et al., 2016; Petaja et al., 2018).

Long-term boreal forest fertilization experiment with repeated application of nitrogen containing fertilizer has showed a positive effect on the growth of trees and, as a result, carbon sequestration (Högberg et al., 2006). It has been estimated that by forest soil fertilization in Latvia can be cumulatively reduced $635,000 \mathrm{CO}_{2}$ eq. in 10 years (Petaja et al., 2018).

Soil quality and the content of organic matter of soil have been relevant topics of studies. The topicality of this study is based on necessity to increase $\mathrm{CO}_{2}$ removals in forest ecosystem and considerable shortand long-term greenhouse gas (GHG) mitigation potential of forest fertilization in hemi-boreal forest stands (Federici et al., 2015). The aim of the research is to evaluate temporal impact of fertilization with wood ash and ammonium nitrate on soil organic carbon stock in forests stands with mineral soils.

\section{Materials and Methods}

\section{Study sites and treatment}

In total, 49 research sites were established in the central and the eastern part of Latvia (Table 1). The dominant tree species in the study sites are Scots pine (Pinus sylvestris L.), Norway spruce (Picea abies (L.) H.Karst.) and birch (Betula spp.). In order to estimate the possible impact of treatment on the organic carbon $\left(\mathrm{C}_{\mathrm{ORG}}\right)$ stock in forest soil, the plots were established in the forest stands with dry mineral soil, naturally wet mineral soil and drained mineral soil. The experimental sites received the following treatment: wood ash (WA), wood ash and ammonium nitrate $\left(\mathrm{WA}+\mathrm{NH}_{4} \mathrm{NO}_{3}\right)$ or 
Table 1

\section{Description of research objects and fertilization}

\begin{tabular}{|c|c|c|c|c|c|c|}
\hline $\begin{array}{l}\text { Soil type and } \\
\text { moisture conditions }\end{array}$ & $\begin{array}{l}\text { Dominant tree } \\
\text { species }\end{array}$ & $\begin{array}{c}\text { Number } \\
\text { of forest } \\
\text { stands }\end{array}$ & $\begin{array}{l}\text { Age of } \\
\text { stands }\end{array}$ & $\begin{array}{l}\text { Dose: } \mathrm{t} * \text { WA or } \\
{ }_{* *} \mathrm{NH} 4 \mathrm{NO} 3 \mathrm{ha}^{-1}\end{array}$ & $\begin{array}{l}\text { Fertilizer } \\
\text { spreading }\end{array}$ & Date of treatment \\
\hline \multicolumn{7}{|c|}{ wood ash treatment } \\
\hline Dry mineral soil & Norway spruce & 3 & $50-54$ & $2 ; 3 \mathrm{t}$ WA & mechanically & $11.2014 ; 05.2017$ \\
\hline Drained mineral soil & Norway spruce & 3 & $44-53$ & $3 ; 4 ; 6 ; 8 \mathrm{t}$ WA & $\begin{array}{l}\text { manually/ } \\
\text { mechanically }\end{array}$ & $\begin{array}{l}\text { 10.2016; 12.2016; } \\
05.2017\end{array}$ \\
\hline \multicolumn{7}{|c|}{ wood ash and ammonium nitrate treatment } \\
\hline Drained mineral soil & Norway spruce & 2 & $36-38$ & $\begin{array}{l}3 \mathrm{t} \mathrm{WA}+ \\
0.44 \mathrm{t} \mathrm{NH} 4 \mathrm{NO} 3\end{array}$ & mechanically & $02.2017 ; 07.2017$ \\
\hline Drained mineral soil & Scots pine & 3 & $51-67$ & $\begin{array}{l}3 \mathrm{t} \mathrm{WA}+ \\
0.44 \mathrm{t} \mathrm{NH} 4 \mathrm{NO} 3\end{array}$ & mechanically & $02.2017 ; 07.2017$ \\
\hline Drained mineral soil & birch & 2 & $34-37$ & $\begin{array}{l}3 \mathrm{t} \mathrm{WA}+ \\
0.44 \mathrm{t} \mathrm{NH} 4 \mathrm{NO} 3\end{array}$ & $\begin{array}{l}\text { manually/ } \\
\text { mechanically }\end{array}$ & $\begin{array}{l}\text { 10.2016; 02.2017; } \\
06.2017 ; 07.2017\end{array}$ \\
\hline \multicolumn{7}{|c|}{ ammonium nitrate treatment } \\
\hline Dry mineral soil & Norway spruce & 7 & $25-83$ & 0.44 t NH4NO3 & $\begin{array}{l}\text { manually/ } \\
\text { mechanically }\end{array}$ & $09.2015 ; 07.2017$ \\
\hline Dry mineral soil & Scots pine & 21 & $24-130$ & $0.44 \mathrm{t} \mathrm{NH}_{4} \mathrm{NO}_{3}$ & $\begin{array}{l}\text { manually/ } \\
\text { mechanically }\end{array}$ & $\begin{array}{l}\text { 09.2015; 06.2017; } \\
07.2017\end{array}$ \\
\hline Dry mineral soil & birch & 3 & $44-72$ & $0.44 \mathrm{t} \mathrm{NH}_{4} \mathrm{NO}_{3}$ & $\begin{array}{l}\text { manually/ } \\
\text { mechanically }\end{array}$ & $06.2017 ; 07.2017$ \\
\hline Wet mineral soil & birch & 2 & $23-48$ & $0.44 \mathrm{t} \mathrm{NH}_{4} \mathrm{NO}_{3}$ & $\begin{array}{l}\text { manually/ } \\
\text { mechanically }\end{array}$ & $05.2017 ; 06.2017$ \\
\hline Drained mineral soil & Norway spruce & 2 & $28-37$ & $0.44 \mathrm{t} \mathrm{NH}_{4} \mathrm{NO}_{3}$ & $\begin{array}{l}\text { manually/ } \\
\text { mechanically }\end{array}$ & $09.2015 ; 06.2017$ \\
\hline
\end{tabular}

*wood ash; **ammonium nitrate

ammonium nitrate $\left(\mathrm{NH}_{4} \mathrm{NO}_{3}\right)$. Control plots $(\mathrm{C})$ were left without the treatment. Wood ash used in this study were taken from local heating- and power plants: NewFuels RSEZ, Ltd.; Latgran, Ltd.; "'Graanul Invest, Ltd. and Salaspils siltums, Ltd.

Collection and analysis of soil samples

Collection of samples was conducted in 2019, namely, 2-5 years after the fertilization. Two replicates of $10 \mathrm{~cm}$ x $10 \mathrm{~cm}$ large $\mathrm{O}$ horizon samples were collected in each plot. Soil samples were collected at fixed depths: 0-10 cm, 10-20 cm, 20-40 cm and 40$80 \mathrm{~cm}$. The samples were taken at each plot, ensuring 2 replicates per plot.

Collected O horizon samples were milled till fine powder, soil samples were manually comminuted and sieved through $2 \mathrm{~mm}$ sieve. Fine fraction was used for analyses assuming coarse fraction to be free of $\mathrm{C}_{\mathrm{ORG}}$ and nitrogen $(\mathrm{N})$. The samples were prepared according to the ISO 11464:2005. Bulk density was determined according to ISO 11272:2017. Content of total carbon $\left(\mathrm{C}_{\mathrm{TOT}}\right)$ content was determined using elementary analysis according to ISO 10694:2006 and inorganic carbon $\left(\mathrm{C}_{\mathrm{CARB}}\right)$ - by volumetric method according to ISO 10693:2014. Concentration of $\mathrm{C}_{\mathrm{ORG}}$ was calculated as the difference: $\mathrm{C}_{\mathrm{TOT}}-\mathrm{C}_{\mathrm{CARB}}$. The concentration of total nitrogen $\left(\mathrm{N}_{\mathrm{TOT}}\right)$ was determined using elementary analysis according to ISO 13878:1998.

Data analysis

The $\mathrm{C}_{\mathrm{ORG}}$ stock was calculated for different soil layers: 0-10 cm, 10-20 cm, 20-40 cm and 40-80 cm. In addition to these soil layers, the average $\mathrm{C}_{\mathrm{ORG}}$ stock in soil from control and fertilized plots was compared in the following soil layers: $0-20 \mathrm{~cm}, 0-40 \mathrm{~cm}$ and $0-80 \mathrm{~cm}$. The $\mathrm{C}_{\mathrm{ORG}}$ stock was calculated according to the formula (1):

(1) $C S=\frac{S B D \times H \times\left(100 \%-P_{2 m m}\right)}{100(\mathrm{~cm})} \times \frac{S O C}{1000}$, where:

$C S$ - content of $\mathrm{C}_{\mathrm{ORG}}$ in 1 ha of the soil/O horizon $\left(\mathrm{t} \mathrm{C}_{\mathrm{ORG}} \mathrm{ha}^{-1}\right)$;

SOC $-\mathrm{C}_{\mathrm{ORG}}$ content $\left(\mathrm{g} \mathrm{kg}^{-1}\right)$;

$S B D$ - bulk density $\left(\mathrm{kg} \mathrm{m}^{-3}\right)$;

$H$ - thickness of a soil/O horizon layer $(\mathrm{cm})$;

$P_{2 m m}-$ volume of the fraction of $>2 \mathrm{~mm}$ particles in the sample $(\%)$. 


\section{Impact of forest soil fertilization on $\mathrm{C}_{\mathrm{ORG}}$ stock ( $\left.\mathrm{t} \mathrm{ha}^{-1}\right)$ in $\mathrm{O}$ horizon (mean values \pm standard error of the mean)}

\begin{tabular}{|l|l|l|l|l|l|l|}
\hline \multicolumn{1}{|c|}{ Type of fertilizer } & \multicolumn{2}{|c|}{ Wood ash } & $\begin{array}{l}\text { Wood ash and } \\
\text { ammonium } \\
\text { nitrate }\end{array}$ & \multicolumn{3}{c|}{ Ammonium nitrate } \\
\hline $\begin{array}{l}\text { Soil type and moisture } \\
\text { conditions }\end{array}$ & $\begin{array}{l}\text { Dry mineral } \\
\text { soil }\end{array}$ & $\begin{array}{l}\text { Drained } \\
\text { mineral soil }\end{array}$ & $\begin{array}{l}\text { Drained } \\
\text { mineral soil }\end{array}$ & $\begin{array}{l}\text { Dry mineral } \\
\text { soil }\end{array}$ & $\begin{array}{l}\text { Wet mineral } \\
\text { soil }\end{array}$ & $\begin{array}{l}\text { Drained } \\
\text { mineral soil }\end{array}$ \\
\hline Control plots & $14.0 \pm 6.5$ & $6.4 \pm 2.4$ & $12.9 \pm 1.6$ & $13.3 \pm 0.9$ & $7.8 \pm 2.3$ & $7.2 \pm 0.9$ \\
\hline Fertilized plots & $12.5 \pm 3.0$ & $11.2 \pm 3.0$ & $9.9 \pm 1.3$ & $11.6 \pm 0.7$ & $8.8 \pm 2.3$ & $8.2 \pm 1.3$ \\
\hline
\end{tabular}

Normal distribution was tested by Shapiro-Wilk normality test. The data ranges were not normally distributed; therefore, non-parametrical test was used. The non-parametrical Wilcoxon rank sum test with continuity correction was used to compare the $\mathrm{C}_{\mathrm{ORG}}$ stock among control plots and plots, where fertilizers were applied. The Spearman's rank correlation was used to compare relationship between $\mathrm{C}_{\mathrm{ORG}}$ and $\mathrm{N}_{\mathrm{TOT}}$ stock of the trial objects. The strength of correlation coefficient was evaluated according to Akoglu (2018). Tests were conducted at a $95 \%$ confidence level in program $R$ (R Core Team, 2018).

\section{Results and Discussion}

The results are summarized according to the applied fertilizer and forest stand type. Table 2 summarizes the average $\mathrm{C}_{\mathrm{ORG}}$ stock in $\mathrm{O}$ horizon. No statistically significant differences were found between control and fertilized plots. No trends in results were found among the trials or forest stand types. No significant impact on O horizon was reported in similar study with wood ash application (Libiete $e t$ al., 2016). The differences in $\mathrm{C}_{\mathrm{ORG}}$ stock among the plots can be explained with the natural $\mathrm{O}$ horizon variability. The average $\mathrm{C}_{\mathrm{ORG}}$ stock in $\mathrm{O}$ horizon is smaller in comparison to average values in Latvia estimated earlier - $21 \mathrm{t} \mathrm{ha}^{-1}$ (Bārdule et al., 2009) or average $\mathrm{C}_{\mathrm{ORG}}$ stock in $\mathrm{O}$ horizon in European forests $22.1 \mathrm{t} \mathrm{ha}^{-1}$ (De Vos et al., 2015). These differences in average $\mathrm{C}_{\mathrm{ORG}}$ stock in $\mathrm{O}$ horizon may be explained with different site conditions of the experiments, because the organic matter content in $\mathrm{O}$ horizon depends on different factors, such as disturbances (Bārdule et al., 2017), moisture regime of the stand (Błońska \& Lasota, 2017) and the dominant tree species of the stand (Butlers \& Lazdins, 2020) while the calculated $\mathrm{C}_{\mathrm{ORG}}$ stock is quite similar to the mean value determined in a study carried out in local Scots pine stands with dry mineral soil $-15.2 \mathrm{t}$ ha ${ }^{-1}$ (Ķēniņa et al., 2019).

The average $\mathrm{C}_{\mathrm{ORG}}$ stock in different soil layers in the research objects after the fertilization are summarized in Table 3. Statistically significant differences $(p<0.01)$ in average $C_{O R G}$ stock were found in upper soil layers $(010 \mathrm{~cm}$ and $1020 \mathrm{~cm})$ in forest stands with wet mineral soil. The average $\mathrm{C}_{\text {ORG }}$ stock in control plots in stands with wet mineral soil is $44.4 \pm 5.3$ and $19.4 \pm 3.8 \mathrm{t} \mathrm{ha}^{-1}$ and $\mathrm{C}_{\mathrm{ORG}}$ stock in plots fertilized with $\mathrm{N}$ containing mineral fertilizer is $29.6 \pm 4.1$ and $11.0 \pm 1.6 \mathrm{t} \mathrm{ha}^{-1}-$ in $0-10 \mathrm{~cm}$ and $10-20 \mathrm{~cm}$ soil layers, respectively. The soil samples were collected in the second year after the ammonium nitrate application in these two birch stands. The soil moisture regime of these trial objects differs from other experimental sites. The average $\mathrm{C}_{\mathrm{ORG}}$ stock of mineral soil determined in this study is comparatively smaller than the average value estimated in the earlier study in Latvia - $195 \mathrm{t} \mathrm{ha}^{-1}$ (Bārdule et al., 2009). But the calculated value is quite similar to results of other local studies $-88.4 \mathrm{t} \mathrm{ha}^{-1}$ in Norway spruce stands with dry mineral soil, $88.0 \mathrm{t} \mathrm{ha}^{-1}$ in stands with wet mineral soil (Ķēniņa et al., 2018) and $90.0 \mathrm{t} \mathrm{ha}^{-1}$ in Scots pine stands with dry mineral soil (Ķēniņa et al., 2019). The calculated values of cumulative $C_{\mathrm{ORG}}$ stock in 0-80 $\mathrm{cm}$ soil layer varies among different plots, but the average value is close to $\mathrm{C}_{\mathrm{ORG}}$ stock determined in European forests in $0-100 \mathrm{~cm}$ mineral soil layer 108 t ha $^{-1}$ (De Vos et al., 2015).

$\mathrm{A}$ trend of smaller $\mathrm{C}_{\mathrm{ORG}}$ stock in upper soil layer $(0-10 \mathrm{~cm})$ of fertilized plots was detected, and to a lesser extent - in $10-20 \mathrm{~cm}$ soil layer. If $\mathrm{C}_{\mathrm{ORG}}$ is summarized at multiple layers, on average the calculated $\mathrm{C}_{\mathrm{ORg}}$ stock is smaller in fertilized plots, except for ammonium nitrate treated plots in forest stands with drained mineral soil. The difference is not statistically significant in the most cases.

The results of Spearman rank correlation between $\mathrm{C}_{\mathrm{ORG}}$ and $\mathrm{N}_{\mathrm{TOT}}$ in $\mathrm{O}$ horizon is shown in Table 4. The table summarizes only statistically significant $(p<0.05)$ results. All relationships detected are positive and ranges from moderate to very strong. The correlation found confirms that the $\mathrm{N}_{\text {TOT }}$ stock is higher in plots with higher content of organic matter in soil. 


\section{Impact of forest soil fertilization on $\mathrm{C}_{\mathrm{ORG}}$ stock $\left(\mathrm{t} \mathrm{ha}^{-1}\right)$ in different mineral soil layers}

\begin{tabular}{|c|c|c|c|c|c|c|c|c|}
\hline \multirow{2}{*}{$\begin{array}{c}\text { Soil type } \\
\text { and moisture } \\
\text { conditions }\end{array}$} & \multirow{2}{*}{ Plot } & \multicolumn{4}{|c|}{$\begin{array}{l}\text { Mean soil } \mathrm{C}_{\mathrm{ORG}} \text { stock in different soil layers (mean } \\
\text { values } \pm \text { standard error of the mean), } \mathrm{t} \mathrm{ha}^{-1}\end{array}$} & \multicolumn{3}{|c|}{$\begin{array}{l}\text { Cumulative soil } \mathrm{C}_{\mathrm{ORG}} \text { stock in } \\
\text { different soil layers, } \mathrm{t} \mathrm{ha}^{-1}\end{array}$} \\
\hline & & $0-10 \mathrm{~cm}$ & $10-20 \mathrm{~cm}$ & $20-40 \mathrm{~cm}$ & $40-80 \mathrm{~cm}$ & $0-20 \mathrm{~cm}$ & $0-40 \mathrm{~cm}$ & $0-80 \mathrm{~cm}$ \\
\hline \multicolumn{9}{|c|}{ Wood ash experiment } \\
\hline \multirow{2}{*}{$\begin{array}{l}\text { Dry mineral } \\
\text { soil }\end{array}$} & ${ }^{1} \mathrm{C}$ & $40.5 \pm 6.7$ & $22.5 \pm 5.2$ & $16.2 \pm 4.6$ & $15.5 \pm 5.5$ & 63.0 & 79.2 & 94.7 \\
\hline & ${ }^{2} \mathrm{WA}$ & $38.4 \pm 9.2$ & $18.1 \pm 2.7$ & $17.5 \pm 5.4$ & $18.2 \pm 3.3$ & 56.5 & 74.0 & 92.2 \\
\hline \multirow{2}{*}{$\begin{array}{l}\text { Drained } \\
\text { mineral soil }\end{array}$} & $\mathrm{C}$ & $66.7 \pm 15.4$ & $30.6 \pm 9.3$ & $19.0 \pm 6.3$ & $52.3 \pm 12.2$ & 97.3 & 116.2 & 168.6 \\
\hline & WA & $43.8 \pm 16.2$ & $41.1 \pm 5.4$ & $31.8 \pm 5.7$ & $33.1 \pm 5.1$ & 84.8 & 116.7 & 149.8 \\
\hline \multicolumn{9}{|c|}{ Wood ash and ammonium nitrate experiment } \\
\hline \multirow{2}{*}{$\begin{array}{l}\text { Drained } \\
\text { mineral soil }\end{array}$} & $\mathrm{C}$ & $62.9 \pm 5.1$ & $36.3 \pm 6.7$ & $29.3 \pm 9.9$ & $41.1 \pm 16.1$ & 99.2 & 128.5 & 169.6 \\
\hline & $\mathrm{WA}+\mathrm{N}$ & $54.5 \pm 4.8$ & $36.0 \pm 6.7$ & $34.6 \pm 14.5$ & $25.3 \pm 6.4$ & 90.5 & 125.1 & 150.4 \\
\hline \multicolumn{9}{|c|}{ Ammonium nitrate experiment } \\
\hline \multirow{2}{*}{$\begin{array}{l}\text { Dry mineral } \\
\text { soil }\end{array}$} & $\mathrm{C}$ & $30.7 \pm 2.3$ & $15.7 \pm 1.3$ & $12.1 \pm 1.0$ & $16.8 \pm 2.3$ & 46.4 & 58.5 & 75.3 \\
\hline & ${ }^{3} \mathrm{~N}$ & $30.9 \pm 2.1$ & $12.8 \pm 0.8$ & $12.4 \pm 1.0$ & $15.4 \pm 1.7$ & 43.7 & 56.2 & 71.6 \\
\hline \multirow{2}{*}{$\begin{array}{l}\text { Wet mineral } \\
\text { soil }\end{array}$} & $\mathrm{C}$ & ${ }^{\mathrm{a}} 44.4 \pm 5.3$ & ${ }^{\mathrm{a}} 19.4 \pm 3.8$ & $7.1 \pm 2.4$ & $12.6 \pm 3.7$ & 63.8 & 71.0 & 83.6 \\
\hline & $\mathrm{N}$ & a $29.6 \pm 4.1$ & ${ }^{\mathrm{a}} 11.0 \pm 1.6$ & $8.9 \pm 3.1$ & $29.0 \pm 10.8$ & 40.7 & 49.5 & 78.6 \\
\hline \multirow{2}{*}{$\begin{array}{l}\text { Drained } \\
\text { mineral soil }\end{array}$} & $\mathrm{C}$ & $63.8 \pm 9.8$ & $32.8 \pm 2.3$ & $14.6 \pm 4.1$ & $15.2 \pm 3.8$ & 96.6 & 111.2 & 126.4 \\
\hline & $\mathrm{N}$ & $61.9 \pm 6.7$ & $45.7 \pm 5.7$ & $32.7 \pm 8.8$ & $21.2 \pm 5.3$ & 107.5 & 140.2 & 161.4 \\
\hline
\end{tabular}

${ }^{1}$ control; ${ }^{2}$ wood ash; ${ }^{3}$ ammonium nitrate; a p $<0.05$

Table 4

Significant Spearman rank correlations $\left(r_{s}, p<0.05\right)$ between $C_{O R G}$ and $N_{\text {TOT }}$ stock in $O$ horizons

\begin{tabular}{|l|c|c|c|c|c|c|}
\hline \multicolumn{1}{|c|}{ Type of fertilizer } & \multicolumn{2}{|c|}{ Wood ash } & \multicolumn{1}{c|}{$\begin{array}{l}\text { Wood ash and } \\
\text { N fertiliz. }\end{array}$} & \multicolumn{3}{c|}{ Ammonium nitrate } \\
\hline $\begin{array}{l}\text { Soil type and } \\
\text { moisture conditions }\end{array}$ & $\begin{array}{l}\text { Dry mineral } \\
\text { soil }\end{array}$ & $\begin{array}{l}\text { Drained } \\
\text { mineral soil }\end{array}$ & $\begin{array}{l}\text { Drained mineral } \\
\text { soil }\end{array}$ & $\begin{array}{l}\text { Dry mineral } \\
\text { soil }\end{array}$ & $\begin{array}{l}\text { Wet mineral } \\
\text { soil }\end{array}$ & $\begin{array}{l}\text { Drained mineral } \\
\text { soil }\end{array}$ \\
\hline Control plots & ${ }^{\mathrm{b}} 0.73$ & - & ${ }^{\mathrm{a}} 0.89$ & ${ }^{\mathrm{a}} 0.85$ & ${ }^{\mathrm{b}} 0.94$ & ${ }^{\mathrm{a}} 0.98$ \\
\hline Fertilized plots & ${ }^{\mathrm{b}} 0.76$ & - & ${ }^{\mathrm{a}} 0.54$ & ${ }^{\mathrm{a}} 0.58$ & - & ${ }^{\mathrm{a}} 0.79$ \\
\hline
\end{tabular}

${ }^{\mathrm{a}} \mathrm{p}<0.01 ;{ }^{\mathrm{b}} \mathrm{p}<0.05$

Table 5 summarizes only statistically significant correlation between $\mathrm{C}_{\mathrm{ORG}}$ and $\mathrm{N}_{\text {TOT }}$ stock in forest soil. The relationship between $\mathrm{C}_{\mathrm{ORG}}$ and $\mathrm{N}_{\text {TOT }}$ is positive and is found in nearly all soil layers, plots and forest stand types. The correlation found between organic matter and $\mathrm{N}_{\text {TОт }}$ can be estimated as moderate or mostly - very strong.

These findings are in line with the results of demonstration project BioSoil (Bārdule et al., 2009), where relationship between the content of $\mathrm{C}_{\mathrm{ORG}}$ and $\mathrm{N}_{\text {TOT }}$ in forest mineral soil was detected $(\mathrm{R} 2=0.82)$.

Significant relationship between relative $\mathrm{C}_{\mathrm{ORG}}$ and $\mathrm{N}_{\text {TOT }}$ stock in forest soil is shown in Table 6 . In comparison to the correlation found between $\mathrm{C}_{\mathrm{ORG}}$ and $\mathrm{N}_{\text {тот }}$ stock (Table 5), correlation between the relative element stocks was found only in a part of stands. A larger $\mathrm{N}_{\text {Tот }}$ stock in mineral soil layer is related to a larger carbon stock.

\section{Conclusions}

1. No significant trends were found in average carbon stock in $\mathrm{O}$ horizon among experimental groups or different growth conditions.

2. In comparison to the control plots, a smaller $\mathrm{C}_{\mathrm{ORG}}$ stock in $0-10 \mathrm{~cm}$ mineral soil layer was detected in the most of the fertilized plots. A statistically significant difference between control and fertilized plots was found in upper soil layers $(0-10 \mathrm{~cm}$ and $10-20 \mathrm{~cm}$ ) of birch stands with wet mineral soil, indicating a possible impact of ammonium nitrate on mineralization of organic matter. However, the differences may be explained also with different moisture regime and initial $\mathrm{C}_{\mathrm{ORG}}$ stock in these experimental sites.

3. There is no significant difference between soil $\mathrm{C}_{\text {ORG }}$ stock in control plots and plots fertilized with wood ash and nitrogen. Similarly, no significant 
Table 5

Significant Spearman rank correlations $\left(r_{s}, \mathbf{p}<0.05\right)$ between $\mathrm{C}_{\mathrm{ORG}}$ and $\mathrm{N}_{\text {Tот }}$ stock in mineral soil layers

\begin{tabular}{|c|c|c|c|c|c|c|c|c|}
\hline $\begin{array}{c}\text { Soil type } \\
\text { and moisture } \\
\text { conditions }\end{array}$ & Plot & $0-10 \mathrm{~cm}$ & $10-20 \mathrm{~cm}$ & $20-40 \mathrm{~cm}$ & $40-80 \mathrm{~cm}$ & $0-20 \mathrm{~cm}$ & $0-40 \mathrm{~cm}$ & $0-80 \mathrm{~cm}$ \\
\hline \multicolumn{9}{|c|}{ Wood ash experiment } \\
\hline \multirow[t]{2}{*}{ Dry mineral soil } & ${ }^{1} \mathrm{C}$ & ${ }^{\mathrm{a}} 0.89$ & ${ }^{\mathrm{a}} 0.92$ & ${ }^{\mathrm{a}} 0.87$ & ${ }^{\mathrm{b}} 0.69$ & ${ }^{\mathrm{a}} 0.95$ & ${ }^{\mathrm{a}} 0.94$ & ${ }^{\mathrm{a}} 0.87$ \\
\hline & ${ }^{2} \mathrm{WA}$ & ${ }^{\mathrm{a}} 0.91$ & ${ }^{\mathrm{a}} 0.95$ & ${ }^{\mathrm{a}} 0.79$ & - & ${ }^{\mathrm{a}} 0.96$ & ${ }^{\mathrm{a}} 0.92$ & ${ }^{\mathrm{a}} 0.85$ \\
\hline \multirow{2}{*}{$\begin{array}{l}\text { Drained mineral } \\
\text { soil }\end{array}$} & $\mathrm{C}$ & ${ }^{\mathrm{b}} 0.94$ & ${ }^{\mathrm{b}} 0.89$ & ${ }^{\mathrm{b}} 0.89$ & - & ${ }^{\mathrm{a}} 0.94$ & ${ }^{\mathrm{a}} 0.93$ & ${ }^{\mathrm{a}} 0.90$ \\
\hline & WA & ${ }^{\mathrm{a}} 0.92$ & ${ }^{\mathrm{a}} 0.87$ & ${ }^{\mathrm{a}} 0.82$ & ${ }^{\mathrm{a}} 0.67$ & ${ }^{\mathrm{a}} 0.92$ & ${ }^{\mathrm{a}} 0.92$ & ${ }^{\mathrm{a}} 0.86$ \\
\hline \multicolumn{9}{|c|}{ Wood ash and ammonium nitrate experiment } \\
\hline \multirow{2}{*}{$\begin{array}{l}\text { Drained mineral } \\
\text { soil }\end{array}$} & $\mathrm{C}$ & ${ }^{\mathrm{a}} 0.74$ & ${ }^{\mathrm{a}} 0.92$ & ${ }^{\mathrm{a}} 0.83$ & ${ }^{\mathrm{a}} 0.86$ & ${ }^{\mathrm{a}} 0.87$ & ${ }^{\mathrm{a}} 0.91$ & a 0.90 \\
\hline & $\mathrm{WA}+{ }^{3} \mathrm{NH}_{4} \mathrm{NO}_{3}$ & ${ }^{\mathrm{a}} 0.71$ & ${ }^{\mathrm{a}} 0.92$ & ${ }^{\mathrm{a}} 0.83$ & ${ }^{\mathrm{a}} 0.80$ & ${ }^{\mathrm{a}} 0.87$ & ${ }^{\mathrm{a}} 0.91$ & ${ }^{\mathrm{a}} 0.91$ \\
\hline \multicolumn{9}{|c|}{ Ammonium nitrate experiment } \\
\hline \multirow[t]{2}{*}{ Dry mineral soil } & $\mathrm{C}$ & ${ }^{\mathrm{a}} 0.96$ & ${ }^{\mathrm{a}} 0.93$ & ${ }^{\mathrm{a}} 0.74$ & ${ }^{\mathrm{a}} 0.56$ & a 0.96 & ${ }^{\mathrm{a}} 0.87$ & ${ }^{\mathrm{a}} 0.71$ \\
\hline & $\mathrm{NH}_{4} \mathrm{NO}_{3}$ & a 0.94 & ${ }^{\mathrm{a}} 0.92$ & ${ }^{\mathrm{a}} 0.81$ & ${ }^{\mathrm{a}} 0.70$ & ${ }^{\mathrm{a}} 0.95$ & ${ }^{\mathrm{a}} 0.88$ & ${ }^{\mathrm{a}} 0.75$ \\
\hline \multirow[t]{2}{*}{ Wet mineral soil } & $\mathrm{C}$ & ${ }^{\mathrm{b}} 0.68$ & ${ }^{\mathrm{a}} 0.99$ & ${ }^{\mathrm{a}} 0.73$ & ${ }^{\mathrm{b}} 0.66$ & ${ }^{\mathrm{a}} 0.90$ & ${ }^{\mathrm{a}} 0.95$ & ${ }^{\mathrm{a}} 0.91$ \\
\hline & $\mathrm{NH}_{4} \mathrm{NO}_{3}$ & ${ }^{\mathrm{a}} 0.76$ & ${ }^{\mathrm{a}} 0.79$ & ${ }^{\mathrm{b}} 0.72$ & ${ }^{\mathrm{a}} 0.74$ & a0 0.89 & ${ }^{\mathrm{a}} 0.85$ & ${ }^{\mathrm{a}} 0.81$ \\
\hline \multirow{2}{*}{$\begin{array}{l}\text { Drained mineral } \\
\text { soil }\end{array}$} & $\mathrm{C}$ & ${ }^{\mathrm{a}} 0.89$ & ${ }^{\mathrm{a}} 0.95$ & ${ }^{\mathrm{a}} 0.91$ & ${ }^{\mathrm{a}} 0.75$ & a 0.93 & ${ }^{\mathrm{a}} 0.97$ & ${ }^{\mathrm{a}} 0.96$ \\
\hline & $\mathrm{NH}_{4} \mathrm{NO}_{3}$ & ${ }^{\mathrm{a}} 0.94$ & ${ }^{\mathrm{a}} 0.97$ & ${ }^{\mathrm{a}} 0.94$ & ${ }^{\mathrm{a}} 0.83$ & ${ }^{\mathrm{a}} 0.97$ & ${ }^{\mathrm{a}} 0.98$ & ${ }^{\mathrm{a}} 0.97$ \\
\hline
\end{tabular}

${ }^{1}$ control; ${ }^{2}$ wood ash; ${ }^{3}$ ammonium nitrate; a $\mathrm{p}<0.01 ; \mathrm{b} \mathrm{p}<0.05$

Table 6

Significant Spearman rank correlations $(r, \mathrm{p}<0.05)$ between relative organic carbon and nitrogen stock (in comparison to the control plots, $\%$ ) in mineral soil layers

\begin{tabular}{|l|c|c|c|c|c|c|c|}
\hline \multicolumn{1}{|c|}{$\begin{array}{c}\text { Soil type and moisture } \\
\text { conditions }\end{array}$} & $0-10 \mathrm{~cm}$ & $10-20 \mathrm{~cm}$ & $20-40 \mathrm{~cm}$ & $40-80 \mathrm{~cm}$ & $0-20 \mathrm{~cm}$ & $0-40 \mathrm{~cm}$ & $0-80 \mathrm{~cm}$ \\
\hline \multicolumn{7}{|c|}{ Wood ash experiment } \\
\hline Dry mineral soil & - & - & - & - & - & ${ }^{\mathrm{b}} 0.94$ & ${ }^{\mathrm{a}} 0.95$ \\
\hline Drained mineral soil & - & - & - & - & ${ }^{\mathrm{b}} 0.94$ & ${ }^{\mathrm{a}} 0.86$ & ${ }^{\mathrm{b}} 0.61$ \\
\hline \multicolumn{7}{|c|}{ Wood ash and ammonium nitrate experiment } \\
\hline Drained mineral soil & - & - & - & ${ }^{\mathrm{b}} 0.89$ & ${ }^{\mathrm{a}} 0.85$ & ${ }^{\mathrm{a}} 0.83$ & ${ }^{\mathrm{a}} 0.84$ \\
\hline \multicolumn{7}{|c|}{ Ammonium nitrate experiment } \\
\hline Dry mineral soil & ${ }^{\mathrm{a}} 0.92$ & ${ }^{\mathrm{a}} 086$ & ${ }^{\mathrm{a}} 0.53$ & ${ }^{\mathrm{a}} 0.53$ & ${ }^{\mathrm{a}} 0.90$ & ${ }^{\mathrm{a}} 0.78$ & ${ }^{\mathrm{a}} 0.72$ \\
\hline Wet mineral soil & - & - & - & - & - & - & ${ }^{\mathrm{a}} 0.88$ \\
\hline
\end{tabular}

${ }^{\mathrm{a}} \mathrm{p}<0.01 ;{ }^{\mathrm{b}} \mathrm{p}<0.05$

reduction or increase of $\mathrm{N}_{\text {тот }}$ stock is found in plots fertilized with wood ash and nitrogen.

4. On average, forest fertilization with wood ash and/ or ammonium nitrate does not have a significant impact on $\mathrm{C}_{\mathrm{ORG}}$ stock in mineral soil 2-5 years after the fertilization.

5. A relationship between $\mathrm{C}_{\mathrm{ORG}}$ and $\mathrm{N}_{\mathrm{TOT}}$ stock in mineral soil was found practically in all plots - both control and fertilized, and in most of the plots a relationship between the stock in $\mathrm{O}$ horizon.
6. The study has to be continued because $2-5$ years period is too short to acquire the impact of fertilization on soil $\mathrm{C}_{\mathrm{ORG}}$ stock.

\section{Acknowledgements}

The study is implemented within the scope of the Forest Sector Competence Center Project "Elaboration of guidelines and modelling tool for greenhouse gas (GHG) emission reduction in forests on nutrient-rich organic soils" (No. 1.2.1.1/18/A/004 P11). 


\section{References}

Akoglu, H. (2018). User's guide to correlation coefficients. Turkish Journal of Emergency Medicine, 18(3), 91-93. DOI: 10.1016/j.tjem.2018.08.001.

Bārdule, A., Bārders, E., Stola, J., \& Lazdiņš, A. (2009). Latvijas meža augšņu īpašību raksturojums demonstrācijas projekta BioSoil rezultātu skatījumā (Forest soil characteristic in Latvia according results of the demonstration project BioSoil). Mežzinātne, 20(53), 105-124. (in Latvian).

Bārdule, A., Laivinšs, M., Lazdinš, A., Bārdulis, A., \& Zadiņa, M. (2017). Changes in the Soil Organic O Layer Composition after Surface Fire in the Dry-mesic Pine Forest in Rucava (Latvia). Baltic Forestry, 23(2), 490-497.

Błońska, E., \& Lasota, J. (2017). Soil Organic Matter Accumulation and Carbon Fractions along a Moisture Gradient of Forest Soils. Forests, 8(11), 448. DOI: 10.3390/f8110448.

Butlers, A., \& Lazdins, A. (2020). Carbon stock in litter and organic soil in drained and naturally wet forest lands in Latvia. In Annual 22 ${ }^{\text {nd }}$ International Scientific Conference 'Research for Rural Development 2020’, 35, 13-15 May 2020 (pp. 47-54). Jelgava, Latvia: Latvia University of Agriculture. DOI: 10.22616/ $\operatorname{rrd} .26 .2020 .007$.

De Vos, B., Cools, N., Ilvesniemi, H., Vesterdal, L., Vanguelova, E., \& Carnicelli, S. (2015). Benchmark values for forest soil carbon stocks in Europe: Results from a large scale forest soil survey. Geoderma, 251-252, 33-46. DOI: 10.1016/j.geoderma.2015.03.008.

Federici, S., Tubiello, F.N., Salvatore, M., Jacobs, H., \& Schmidhuber, J. (2015). New estimates of CO2 forest emissions and removals: 1990-2015. Forest Ecology and Management, 352, 89-98. DOI: 10.1016/j. foreco.2015.04.022.

Högberg, P., Fan, H., Quist, M., Binkley, D., \& Tamm, C.O. (2006). Tree growth and soil acidification in response to 30 years of experimental nitrogen loading on boreal forest: NITROGEN LOADING ON BOREAL FOREST. Global Change Biology, 12(3), 489-499. DOI: 10.1111/j.1365-2486.2006.01102.x.

Jansons, Ā., Matisons, R., Krišāns, O., Džeriņa, B., \& Zeps, M. (2016). Effect of initial fertilization on 34-year increment and wood properties of Norway spruce in Latvia. Silva Fennica, 50(1). DOI: 10.14214/sf.1346.

K̦ēniņa, L., Elferts, D., Bāders, E., \& Jansons, Ā. (2018). Carbon Pools in a Hemiboreal Over-Mature Norway Spruce Stands. Forests, 9(7), 435. DOI: 10.3390/f9070435.

Ķēniņa, L., Jaunslaviete, I., Liepa, L., Zute, D., \& Jansons, Ā. (2019). Carbon Pools in Old-Growth Scots Pine Stands in Hemiboreal Latvia. Forests, 10(10), 911. DOI: 10.3390/f10100911.

Libiete, Z., Bardule, A., \& Lupikis, A. (2016). Long-term effect of spruce bark ash fertilization on soil properties and tree biomass increment in a mixed scots pine-Norway spruce stand on drained organic soil. Agronomy Research, 14(2), 495-512.

Okmanis, M., Kalvis, T., \& Lazdina, D. (2018). Initial evaluation of impact of evenness of spreading wood ash in forest on additional radial increment. In $17^{\text {th }}$ International Scientific Conference Engineering for Rural Development 23-25 May, 2018 (pp. 1902-1908). Jelgava. DOI: 10.22616/ERDev2018.17.N491.

Okmanis, M., Skranda, I., Lazdins, A., \& Lazdina, D. (2016). Impact of wood ash and potassium sulphate fertilization on growth of Norway spruce stand on organic soil. In $22^{\text {nd }}$ International Scientific Conference 'Research for Rural Development 2016', 2, 18-20 May, 2016 (pp. 62-68). Jelgava, Latvia: Latvia University of Agriculture.

Pan, Y., Birdsey, R.A., Fang, J., Houghton, R., Kauppi, P.E., Kurz, W.A., ... Hayes, D. (2011). A Large and Persistent Carbon Sink in the World's Forests. Science, 333(6045), 988-993. DOI: 10.1126/science.1201609.

Petaja, G., Okmanis, M., Makovskis, K., Lazdiņa, D., \& Lazdiņš, A. (2018). Forest Fertilization: Economic Effect and Impact on GHG Emissions in Latvia. BALTIC FORESTRY, 24(1), 9-16.

R Core Team. (2018). R: A language and environment for statistical computing. Vienna, Austria: R Foundation for Statistical Computing. Retrieved February13, 2021, from https://www.R-project.org/.

Walsh, E., \& McDonnell, K.P. (2012). The influence of added organic matter on soil physical, chemical, and biological properties: a small-scale and short-time experiment using straw. Archives of Agronomy and Soil Science, 58(sup1), S201-S205. DOI: 10.1080/03650340.2012.697999. 